\title{
Menjejaki Situs Kerajaan Kuna Di Kalimantan (Observasi Lapangan Di Empat Provinsi)
}

\section{Suwedi Montana}

Keywords: survey, literature studies, toponym, kingdoms, Borneo

\section{How to Cite:}

Montana, S. Menjejaki Situs Kerajaan Kuna Di Kalimantan (Observasi Lapangan Di Empat Provinsi). Berkala Arkeologi, 15(3), 208-214. https://doi.org/10.30883/jba.v15i3.696

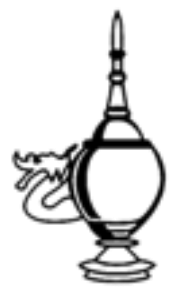

\section{Berkala Arkeologi}

https:/ / berkalaarkeologi.kemdikbud.go.id/

Volume 15 No. 3, 1995, 208-214

DOI: $10.30883 /$ jba.v15i3.696

\section{c) $\$(2)$}

This work is licensed under a Creative Commons Attribution-NonCommercialShareAlike 4.0 International License. 


\title{
MENJEJAKI SITUS KERAJAAN KUNA DI KALIMANTAN (OBSERVASI LAPANGAN DI EMPAT PROVINSI)
}

\author{
Suwedi Montana \\ (Pusat Penelitian Arkeologi Nasional)
}

\section{Pendahuluan}

Selama 12 tahun (1982-1994) penulis te-lah sepuluh kali meneliti empat Provinsi di Kalimantan. Pada setiap kali melakukan penelitian setrap kali pula senantiasa tertarik pada namanama tempat atau kerajaan di Kalimantan yang disebut-sebut dalam karya tulis Prapanca yaitu Nagarakrtagama, yang ditulis pada bulan Aswina 1287 C atau September 1365 (Slametmulyana,1952). Selalu timbul pertanyaan dalam hati apakah tempat, pelabuhan, kerajaan yang sekarang tinggal namanya saja seperti Sampit, Sedu, Katingan, dan Kapuhas itu adalah bekas kerajaan-kerajaan kuna yang pada abad 14 sudah lama berdiri dan menjadi kerajaan yang memberikan upeti kepada Kerajaan Majapahit. Selalu pula terbayang abad 14 tempat-tempat itu menjadi pusat pemerintahan, pusat perekonomian, pusat budaya sebuah negara/kerajaan yang mempunyai kebebasan mengelola pemerintahannya, mempunyai kebebasan mengadakan hubungan dengan negara lain yang jauh letaknya. Bayangan itu menjadi lebih kuat lagi setelah menyimak beritaberita tentang eksistensi kerajaan-kerajaan itu dalam sumber tertulis. Sumber tertulis Eropa abad 16 masih menyebutkan kerajaan-kerajaan tersebut.

Berangkat dari keinginan itu maka dalam makalah ini mencoba menemukan dan menelusuri apa yang pernah ada melalui bukti-bukti yang ada. Investigasi itu meliputi letak bekas kerajaan apakah masih ada pada saat ini; bagaimana status kerajaan itu pada masa sekarang; dan didasarkan pada tinggalan arkeologis yang ada; serta tradisi lisan yang masih hidup hingga kıni. Di samping itu berita-berita tertulis akan dibahas dalam makalah ini.

\section{Berita-berita Pendukung}

Akhir abad ke-15 Bujangga Manik menulis tentang Topografi Jawa. Bujangga Manik adalah seorang pendeta dari Pakuan yang melakukan perjalanan dari Pakuan ke Jawa Tengah dan Jawa Timur. Kemudian pada perjalanannya yang kedua ia mengunjungi Bali, dan kembali dari perjalanan kedua itu ia singgah di berbagai tempat di daerah Sunda sampai akhir hidupnya. Selama dua kali perjalanan itu dijumpainya nama-nama sebanyak 450 buah kebanyakan berhubungan dengan nama-nama tempat (kota), daerah, su- ngai, gunung, dan tempat-tempat suci sepanjang route yang dilaluinya.

Naskah ini ditulis pada masa pra Islam yang menyebutkan kebesaran pengaruh Jawa. Naskah ini tidak menyinggung adanya pengaruh agama Islam di dalamnya (J.Noorduyn, 1982: 412-414) Sebaigamana telah diketahui perkiraan berdirinya kerajaan Islam di Jawa (Demak) seki-tar tahun 1470-an. Hal tersebut menunjukkan bahwa naskah ini ditulis sebelum tahun tersebut Ini mengandung arti bahwa paling tidak 450 buah nama tempat, tempat suci, gunung, danau, dan sungai di Jawa dan Bali itu sudah ada sebelumnya. Boleh dikatakan naskah Bujangga manik dalam menyebutkan nama-nama tempat tersebut didasarkan pada naskah Nagarakrtagama, yang selanjutnya dilengkapi dalam naskah ini. Sayangnya naskah ini dikhususkan untuk nama-nama tempat di Jawa dan Bali sehingga tidak dapat dijadikan bahan pembanding dalam menjejaki kerajaan-kerajaan kuna di kalimantan.

Selama ini masih diragukan kedudukan Nagarakrtagama sebagai sumber sejarah sebab naskah ini merupakan pujasastra sehingga obyektivitas atas penguasa Majapahit tidak seluruhnya benar. Muljana membantah bahwa Prapanca adalah pendeta istana, menurut Mulyana, Prapanca adalah mantan tokoh istana yang dikucilkan, sehingga dalam karyanya itu ia memakai pseudoname Prapanca berarti celaka, sedih atau susah (Slametmuljana, 1952:33). Dengan demikian pencantuman nama-nama kerajaan di Nusantara itu sebagai pemberi upeti (Pigued,1960:11) kepada Majapahit dapat dipertanggungjawabkan kebenarannya. Pemberian upeti bukan berarti sebagai daerah takluk atau jajahan, melainkan ada ikatan kesatuan sederajat atau mitreka satata (Uni Negara-Negara Nusantara).

Penyebutan kerajaan-kerajaan di Kalimantan disebutkan pula dalam Nagarakrtagama pada Canto (Pupuh) 13 dan 14

Canto 13

2.

len tekang nusa tanjung nagara $n$ kapuhas lawan $n$ katingan, sampit/mwang kutalingga mwang i kutawaringin/sambas mwang i la-wai. Canto 14

1. kadangdang i landa len i samdang tirm tan kasah, $n$ sedu burandeng i kalka 
ii sedu burandeng ii kalka saludung solot pasir, baritw i sawaku muwah ritabalung $n$ tanjung kute, lawan i malano makapramukha ta ta ri tanjungpuri

Penyebutan nama-nama kerajaan di kalimantan itu menimbulkan berbagai tafsir apakah Prapanca dalam menuliskan nama-nama itu sekedar mengingat sehingga sekuensanya tidak tepat. Ataukah saat itu Prapanca masih menjabat di istana sehingga dapat memperhatikan peristiwa penghadapan kepada raja. Tampakanya kemungkinan pertama yang menunjukkan kebenaran, hal tersebut terbukti Prapanca menyebutkan nama Malano berdekatan dengan Tanjung Kute, atau Pasir berdekatan dengan Barito dan Sebuku dengan Tabalung. Hal tersebut menunjukkan bahwa Prapanca tidak tahu benar lokasi sebenarnya.

Nagarakrtagama seperti diketahui ditulis tahun 1365, kemungkinkan kerajaan-kerajaan di kalimantan sudah ada sebelum tahun tersebut. Oleh karena itu boleh jadi Nagarakrtagama merupakan sumber berita tertua yang menyinggung kerajaan-kerajaan Kalimantan meskipun ada berita dari Cina. Tampaknya kontak orang Cina dengan orang Kalimantan tidak begitu erat. Hal tersebut terbukti setelah memberitakan tentang Po-lo (pa-ia,Pa-ra) di Kalimantan, tidak menyebutkan Kalimantan bagian mana, selanjutnya tidak ada berita lain mengenai Kalimantan. Baru dalam sejarah Dinasti Ming (1318-1643) diberitakan tentang serbuan tentara Sulu terhadap Puni, bagian barat laut Kalimantan, dan menduduki kerajaan itu. Setelah datang bala bantuan dari Jawa maka tentara pendudukan di Puni meninggalkan tem-pat itu (Groenveldt,1876:103). Kedatanagan bala bantuan dari Jawa tersebut terjadi pada masa keJayaan Majapahit, sekitar pertengahan abad 14. Berita tentang Banjarmasin disebutkan sebagai kota yang dikelilingi dinding kayu berarah hadap ke gunung. Raja Banjarmasin jika berpergian menunggang gajah diiringi dayang-dayang yang membawa pakaian, sepatu, tempat sirih, pisau dan pedang (Ibid: 106). Tidak jelas mengenai je-nis gajan tersebut apakah asli Kalimantan, atau-kah gajah dari Sumatra atau India?.

\section{Letak Kerajaan-kerajaan Kuna}

Beberapa bekas kerajaan itu sampai sekarang masih dapat dilacak atau dijejaki dan masih memiliki nariza, tetapi sebagian sudah tidak diketahui lagi. Hal tersebut disebabkan pergantian nama dan kedudukan administratif kerajaan itu sudah beralih fungsi menjadi sebuah desa kecil. Sementara itu kerajaan-kerajaan tersebut memiliki posisi penting dalam percaturan politik dan ekonomi di Nusantara ini.
Dari sekian kerajaan itu yang masih menjadi teka-teki karena belum dapat dilacak kembali ialah Kutalingga,Lawai, Kadandangan, Samdang, Tirem, Sedu, Kalka, Saludung, Solot, dan Tanjungpura. Semua nama-nama kerajaan di Kalimantan itu terletak di pesisir laut dan di tepi sungai, oleh karena itu tempat-tempat itu selain berfungsi sebagai ibu kota juga sebagai bandar.

Nama Kapuhas secara analog merupakan nama sungai Kapuas di Kalimantan Barat, tetapi disebutkan Kapuhas berdekatan dengan Katingan, maka Kapuhas yang dimaksud adalah Kuala Kapuas, Kalimantan Tengah. Sekarang lokasi tersebut berfungsi sebagai ibu kota kabupaten. Nama Kutawaringin yang kini secara administratif sebagai Kecamatan Kotawanngın Lama, Kabupaten Kotawaringin Barat, Kalimantan Tengah. Apakah yang dimaksud dengan Kutawaringin dalam Nagarakrtagama itu sama dengan itu, perlu penelitan lebih lanjut. Temuan arkeologis klasik tidak mendukung hal itu, justru temuan prasejarah berupa sebuah nekara perunggu berukuran besar.

Kerajaan Sambas terdapat di sekitar kota Sambas sekarang dan merupakan sebuah kota kecamatan, Kabupaten Sambas. Kerajaan Sedu dapat ditafsir nama kota Kecamatan Sedau (sedau-sedo-sedu) sebuah kecamatan di kabupaten Sambas, $6 \mathrm{~km}$ selatan Singkawang. Sedau menjadi pemukiman Cina yang berpangupajiwa membuat keramaian (terkenal:sakok) letaknya di tepi pantai laut. Kalau Seludung sama dengan ucapan Silindung atau Selindung maka mingkin kerajaan itu terdapat di Sambas juga, di daerah perbukitan Pemangkat. Di tempat ini ditemukan tinggalan prasejarah (nekara). Kerajaannya di pedalaman tetapi pantainya di Pemangkat. Peta 1938 dan peta Slametmuljana mencantumkan saludung di Sabah, Kalimantan Utara. Buruneng jelas sebagai Brunai sekarang sedangkan Landa adalah Landak, mungkin kerajaannya ini terietak di tepi sungai Landak yang membuang airnya di sungai Kapuas. Kerajaan Pasir dalam penelitian arkeologi tahun 1992 tidak terdapat pada bekas Pasir Balengkong sekarang, tetapi di desa tua Pasir Mayang (dulu bernama Pasir Lama). Terletak di muara sungai dekat Teluk, Kalimantan Timur. Temuan arkeologis berupa keramik kuna menunjukkan bahwa Pasir Mayang. Kecamatan Kuaro, Kabupaten Pasir adalah bekas pemukiman kuna.

Kerajaan Baritu dapat dipastikan terdapat di kalimantan Tengah di tepi kali Barito. Demi-kian pula kerajaan Sawuku adalah sebuah pulau Sebuku, Kalimantan Selatan. Sedangkan kerajaan Tabalung terletak di tepi Batang Tabalong. Kerajaan Tabalong diperkirakan terdapa: di Desa 
Banua Lawas (banua-desa; lawas-lama). Tinggalan arkeologis berupa tumpukan batu bata besar dekat Mesjid kuna Banua Lawas. Kabupaten Tabalong.

Adapun Kerajaan Tanjung Kute merupakan permasalahan tersendiri, karena beberapa pakar berpendapat lain, hal ini berhubungan dengan kerajaan pelabuhan versi berita Portugis. Kerajaan Malano terdapat di teluk Melano di pantai Kalimantan Barat. Kabupaten Ketapang, sekarang berkedudukan di Kecamatan Teluk Melano.

\section{Sumber Berita Portugis}

Berita Portugis banyak membicarakan kota-kota pelabuhan yang sekaligus berfungsi sebagai ibu kota kerajaan di Kalimantan. Meskipun berita itu ditulis lebih kemudian tetapi karena dilengkapi penjelasan-penjelasan dan peta, serta diberi tafsir komentar oleh penerjemah laporan itu maka kedudukan sumber berita itu boleh dikata agak akurat.

Tome Pires adalah perantau yang menulis. kan pelayarannya dalam The Sưmą Qriental of Tome Pires and tehe Book of Francisco Rodriggues From Red Sea to Japan written in Malacca and India in 1512-1515. Tulisan itu menyebutkan nama pelabuhan di Kalimantan ialah Tanyompura, Laue, Quedom-doam, Samper, Pamuca, dan Cate

Menurut Tome Pires, Tanjaompura terletak di sebuah pulau yang dapat ditempuh dari Mala-ka selama 15 hari pelayaran. Penduduknya ma-sih heathens (kafir). Seluruh pulau merupakan wilayah Pate Unus, raja Jepara. Pemimpin pulau disebut Pate (path, adipati) berkedudukan sebagai Gubernur Wilayah. Luas Tanyaompura 50 leagues (1leaguess - 1796 ha). Tanahnya mengandung emas - intan dan subur. Penduduk banyak memiliki jung dan pangajawa. Hubungan dagang dilakukan dengan Jawa dan Malaka. Pedagang dari luar membeli emas, intan dan bahan makanan. Mutu intan Tanyaompura lebih baik daripada intan Orissa di India. Tanyaompura juga menghasilkan madu dan lilin (lebah).

Di Laue banyak ditemukan intan, jarak antara pelabuhan dengan Tanyaompura 4 hari pelayaran. Laue berpenduduk padat, mereka lebih banyak berdagang dengan Jawa daripada dengan Malaka. Komoditi dagang yang masuk ke pelabuhan Tanyaompura dan Laue ialah kain Keling, kain Bretangi warna merah dan hitam. Penduduk Samper masih heathens dan diperintah oleh seorang Pate. Pelabuhan Samper banyak mengirimkan tikar, rotan, ikan kering, damar, sayur-mayur, dan anggur (mungkin tuak dari pohon enau atau kelapa atau anggur dari beras)
Penyebutan pelabuhan atau ibu kota kerajaan Tanyaompura berdasarkan peta buatan Bartheloot (1635) sama dengan Tan-Yao-Pute terletak pada $30^{\circ} 31$ 'LS. Letak itu cocok dengan legenda Tanjung Puting sehingga Tan-Yao-Pute mengacu pada Tanjung Puting yang daerah hinterlandnya sama dan saat ini merupakan suaka margasatwa orang utan. Sementara itu, Casthahenda menerangkan di Tan-Yao-Pute terdapat tambang intan yang sudah lama diekploitasikan.

Nama Laue cocok dengan Lawai dalam Negarakrtagama. Kabupaten Sintang pada masa lampau pernah terdapat onderafdeeling Melawi letaknya di tepi sungai Melawi. Tempat itu terlalu jauh dari pantai laut $(500 \mathrm{~km}$ dari Pontianak). Dugaan (Me) Lawi sama dengan (Me) Lawai atau Lawe agak diragukan. Di pedalaman Kalimantan Tengah terdapat Sungai Mendawai yang membuang airnya di Teluk Sampit, selain itu terdapat pula kampung kuna Mendawai di Kota Pangkalan Bun (ibu kota Kotawaringin Barat) di tepi sunga Arut. Perubahan ucapan yang biasa terjadi da-lam bahasa-bahasa Nusantara, bunyi $r$ dapat ber-ubah menjadi r, l, d, g, h, boleh jadi Lawai sama dengan (men)Dawai. Tetapi kalau kerajaan Mendawai terletak di hulu sungai Sampit jarak antara kedua kerajaan (mendawai dan Sampit) terlalu dekat. Kemungkinan Mendawai merupakan sebuah kampung lama di Pangkalan Bun. Jarak antara Lawai (Dawai) dengan Tanjungpura sekitar 4 hari pelayaran. Perjalanannya menyusuri pantai melalui Teluk Tanjung Puting, pelabuhan Kumai dan memudiki sungai Arut sampai ke (Men) Dawai. Pernyataan van Ned-Oost Indie mementahkan asumsi tersebut. Hal tersebut karena dalam Ency dicantumkan Mendawai atau Katingan adalah wilayah Onderafdeeling Kuala Kapuas yang pada tahun 1826 masih menjadi wilayah Kesultanan Banjarmasin. Kemungkinan Mendawai di pangkalan Bun adalah Lawai abad ke 14

Kerajaan Tanjungpura terletak di tepi Sungai Pawan, Kecamatan Matan, Ketapang. Dugaan ini dibuktikan dengan hasil temuan arkeologi Sebaliknya Quedom-doam oleh Tome Pires ditafsirkan terletak antara Tanyaompura dan Laue. Kemungkinan yang dimaksudkan adalah Kedondong yaitu Ketapang.

Bukti arkeologis, di Ketapang yaitu inskripsi Jawa Kuna dalam bentuk angka tahun. Inskrips itu menyebutkan dua lokasi kubur muslim kuna di Desa Mulyakerta yang dikenal dengan nama Makam Keramat Tujuh, dan di Desa Negeri Baru kelompok Makam Keramat Sembilan. Hal yang menarik pada batu-batu nisan berangka tahun Jawa Kuna ialah bentuknya sama dengan batubatu nisan yang ada di Pemakaman kuna Tralaya, Majakerta. Kita ketahui bahwa Tralaya ada- 
Iah necropolis ibu kota Majapahit. Bahkan salah satu di antara batu nisan di Makam Keramat Sembilan diberi medali berbentuk lambang kebesaran atau Regalia Kerajaaan Majapahit yang oleh para pakar dari Perancis dinamakan Soteil de Majapahit, yaitu lingkaran bersudut-sudut yang merupakan sinar matahari (Foto 1 dan 2).

Tokoh yang dikuburkan dalam kedua kelompok makam itu tidak diketahui sebab selain angka-angka tahun Jawa kuna hanya ada inskripsi Arab tentang ayat-ayat pendek dari Al Quran. Dalam kelompok Makam Keramat Tujuh terdapat 3 pasang batu nisan, dua pasang di antaranya sama, yaitu

$1363 \mathrm{~S}-1441 \mathrm{M}$
$1363 \mathrm{~S}-1441 \mathrm{M}$
$1340 \mathrm{~S}-1418 \mathrm{M}$

Kelompok Makam Keramat Sembilan terdapat 4 pasang batu nisan berangka tahun Jawa kuna:

$1354 S-1432 M$
$1354 S-1432 M$
$1360 S-1438 M$
$1359 S-1437 M$

Inskripsi Jawa kuna itu terdapat pada nisan kaki bagian luar, sedangkan ayat Al Quran terdapat pada nisan kepala bagian dalam.

Dengan temuan itu adalah tidak benar bahwa masyarakat di pesisir Kalimantan Barat masih heathens seperti dikatakan oleh Tome Pires. Temuan tersebut juga memperjelas bukti kesamaan waktu alamisasi dengan pedalaman Jawa (Majapahit) sebab rentetan angka tahun itu tidak jauh berbeda dengan tahun-tahun di Tralaya, hanya di sini lebih banyak jumlahnya dan yang paling tua tahun $1296 \mathrm{~S}$ atau $1373 \mathrm{M}$.

\section{Letak Cate, Tirem, Dan Kedondong}

Nama Cate (Tome Pires) lebih mendekati nama Kute, sebuah kerajaan pada masa pra Islam merupakan kesinambungan kerajaan Mulawarman (abad ke 5) di Kalimantan Timur. Tome Pires cenderung berasumsi merupakan kota di Pulau Laut yaitu Kotabaru. Kute atau Cate kini tidak berada di Kutai (Tenggarong), melainkan di Desa Kutai Lama pada muara sungai Mahakam Kecamatan Anggana, Kabupaten Kutai. Temuan arkeologi adalah sebuah yoni dan makam kuna Sultan Kutai Kertanegara yang pertama kali masuk Islam. Adapun nama Pamuca, kiranya merupakan Teluk Pamukan di pantai timur Kalimantan Selatan. Kemungkinan Kerajaan Pamukan pada abad ke 16 terletak di Teluk Pamukan.

Penyebutan Tirem dan Kedondong, menurut Slametmuljana dalam peta Majapahitnya mencantumkan Tirem di muara sungai Mahakam tepat di Desa Kutai Lama, sedangkan peta tahun 1938, Tirem terletak di dekat Pontianak, demikian pula Pigued berasumsi Tirem terletak di selatan Pontianak, sekitar Ketapang

Kabupaten Ketapang mempertahakan lambang daerah berupa kulit kerang atau ala-ala yaitu sejenis kerang tak bergigi yang khusus hidup di kuala Sungai Pawan. 'Kota Ketapang terletak di kuala sungai itu. Binatang ala-ala menjadi makanan khas penduduk yang dikonsumsi sejak lama. Daerah ini terkenal dengan produk ala-ala, sehingga binatang itu dijadikan lambang daerah. Di samping lambang ala-ala dipakai juga lam-bang pohon kedondong. Penggunaan lambang pohon kedondong sebagai lambang daerah itu didasarkan atas mitos pohon kedondong yang tumbuh di Ketapang. Kata Kedondong oleh Tome Pires dilafaskan pelabuhan Quedom-doam, yaitu Kedondong kota Ketapang sekarang. Berarts pada tahun 1512 Kedondong atau Quedom-doam sudah menjadi kota pelabuhan yang populer.

Ala-ala adalah sejenis kece, remis, dan kerang secara umum oleh masyarakat Jawa dike-nal sebagai tirem. Produksi ala-ala atau tirem yang besar dari daerah ini menyebabkan daerah ini dikenal sebagai negeri Tirem yaitu negeri yang menghasilkan tirem. Sehubungan dengan itu yang dimaksud Kerajaan Tirem oleh Prapanca diperkirakan Ketapang. Jika dugaan itu benar maka kota Ketapang sudah dikenal pada abad ke 14 sebagai Kerajaan Tirem yang bertetangga dengan Tanjungpura, Melano dan Kadandangan, dan pada tahun 1512 kota ini dikenal dengan sebutan Quedom-doam oleh perantau bangsa Portugis dan ucapan itu mengacu pada sebutan Kedondong.

\section{Kesimpulan}

Dari penjejakan dan pentafsiran kerajaankerajaan kuna di Kalimantan untuk sementara dapat disimpulkan bahwa Kerajaan-kerajaan kuna itu ada dan pemah mengalami masa keemasan. Kerajaan-kerajaan itu cukup terkenal terbukti disebut-sebut dalam laporan tertulis baik lokal maupun international. Akhimya untuk menjejaki eksistensi kerajaan-kerajaan dengan didukung bukti arkeologis masih perlu dilakukan secara lebih akurat.

\section{KEPUSTAKAAN}

Cortesao, Armando,1944. The Suma Oriental of Tome Pires and The Book of Francisco Rodrigues. From the Red Sea to Japan written in Malacca and India in 15121515. Liechenstein. 
Endang Sri Hardiyati, 1993, Laporan Penelitian Arkeologi diKabupaten Ketapang, Kalimantan Barat (Belum terbit) Bagian Proyek Penelitian Purbakala Banjarmasin 1993/ 94

Goenadi Nitihaminoto,dkk, 1977, Laporan Hasil Survey Kepurbakalaan di Propinsi Kalimantan Barat. BPA No.6, Jakarta.

Groeneveldt,WP, 1876, Notes on the Malay Archipelago and Malacca complied from the Scources. VBG. 39, S'Hage.

Montana,Suwedi,1993, Sebuah Teka-Teki Mesi-git Agung di lbukota Majapahit. Kebuda-yaan No. 4 Th 1992/1993, Jakarta:Dep. P dan K.

-1994,Berita-berita Lama tentang Kotawringin dan Inskripsi Jawa Kuna yang unik. Kebudayaan No. 7 Th 1994 Jakarta:Dep. P dan $\mathrm{K}$
---1994, Tinggalan Arkeologi islam di Daerah Ketapang kalimantan Barat. Jakarta: Pusat Penelitian Arkeologi Nasional.

Paulus,J.,1917, Encyclopedie van Ned-Oost Indie I \& II, Leiden.

Slametmuljana,1952,Adakah Prapanca sungguh Pujangga Keraton? Bahasa dan Budaja No. 2 Th.J. Desember 1952.

1979, Nagarakrtagama dan tafsir sejarahnya. Jakarta:Bhratara.

Pigeaud,Th.G.Th.,1960, Java in the Fourteenth Century A Study in Cultural History I \& III. Leiden. 


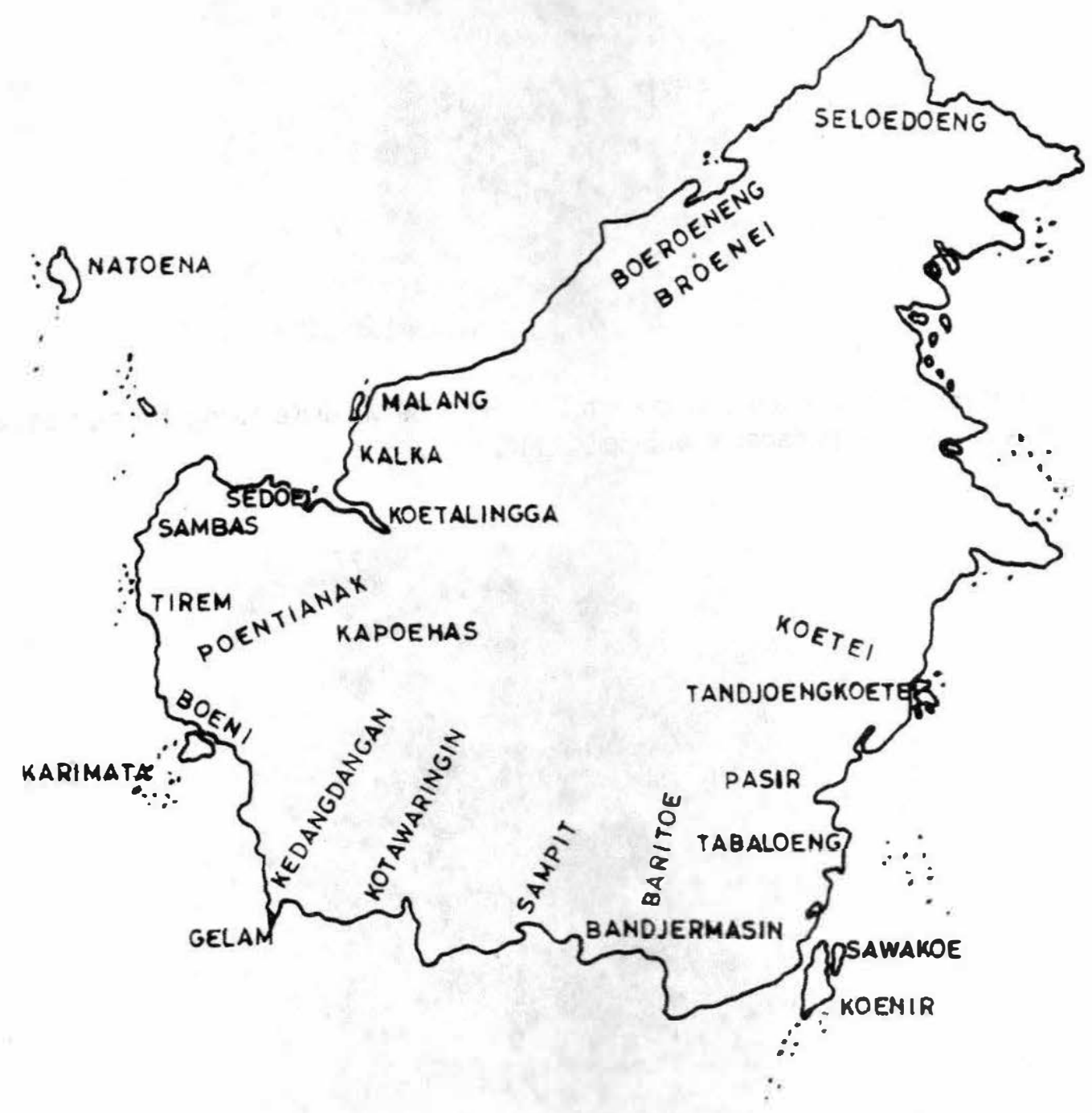

Repro dari ATLAS VAN TROPISCH

NEDERLAND $1938 \mathrm{hal} 10$ 


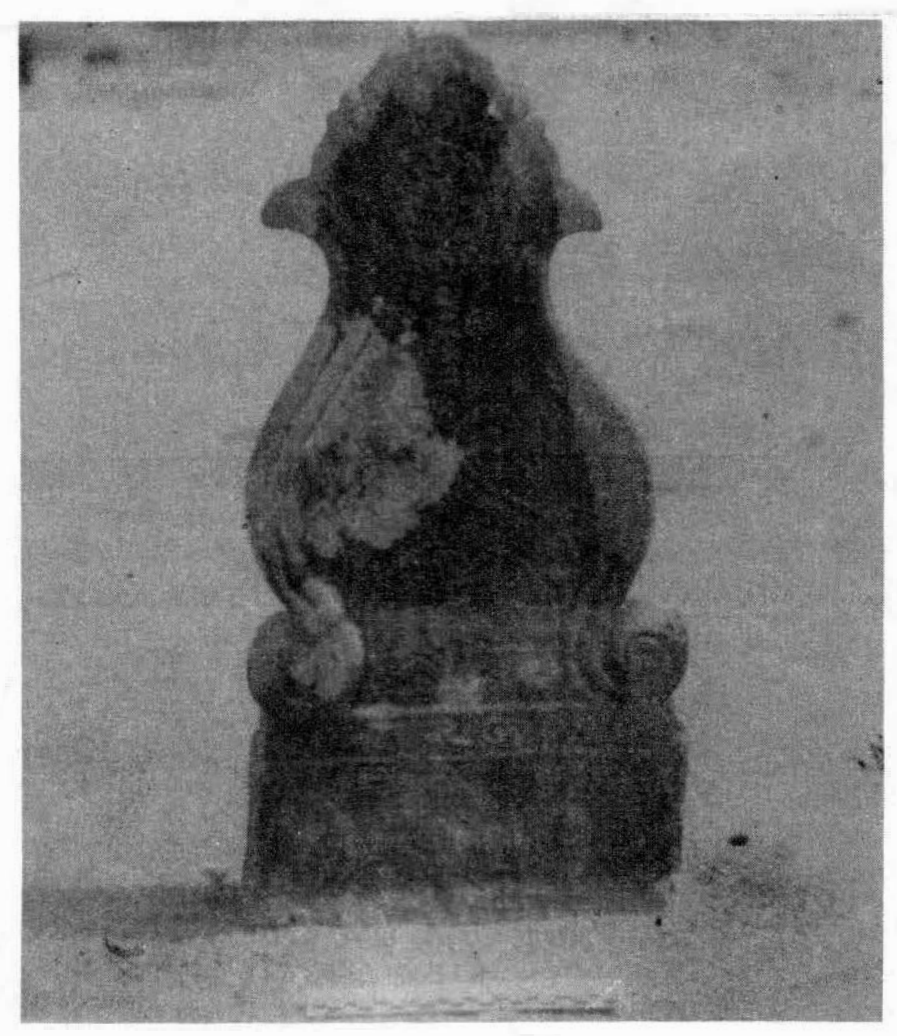

Foto 1. Batu Nisan berangka tahun Jawa kuna 1311 S ( 1389 M ) di Ketapang, Kalimantan Barat. Pada bagian atas terdapat relief Soleil de Majapahit

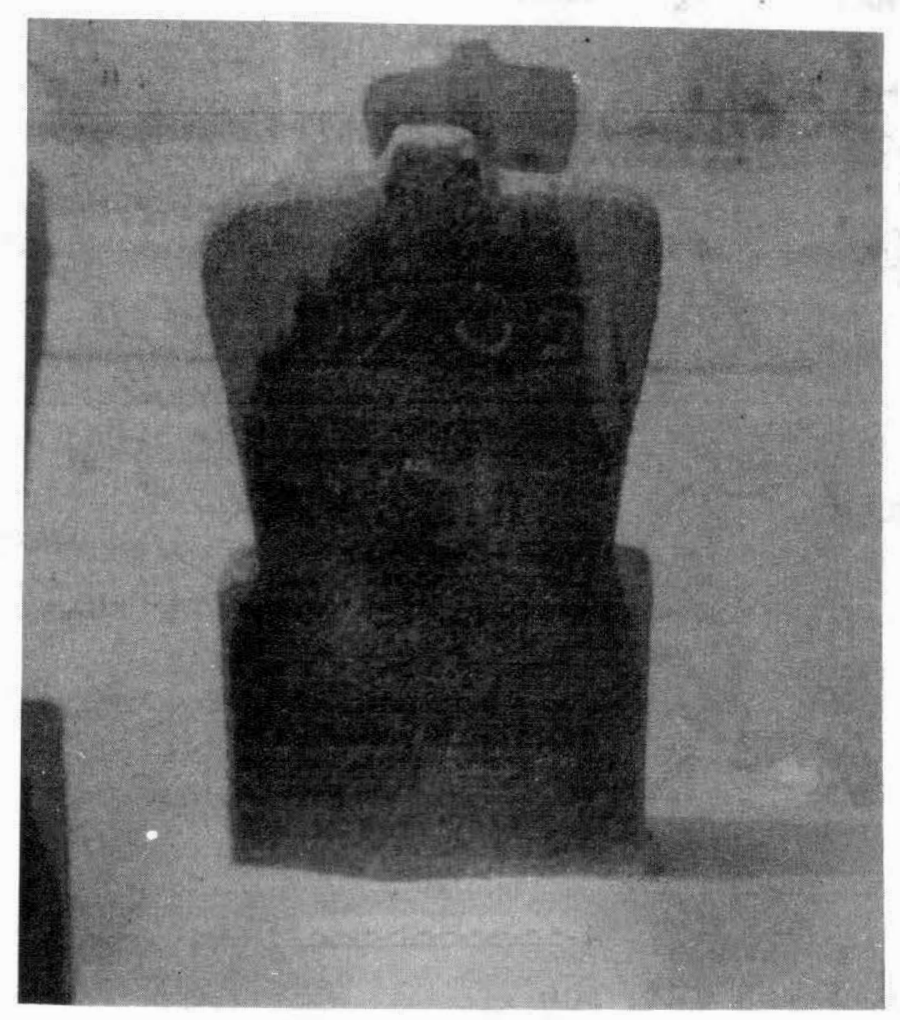

Foto 2. Batu Nisan tipe Tralaya (Majapahit) di Ketapang, Kalimantan Barat, berangka tahun Jawa kuna 1354 S( 1432 ) 